\title{
SEJARAH PEMIKIRAN EKONOMI ISLAM
}

\section{“Konsep Ekonomi Pada Masa Bani Umayyah, Abbasiyah dan Turki Utsmani”}

( Satriana 90100118038 )

Sektor pembangunan di bidang ekonomi merupakan masalah sentral dalam pembangunan suatu negara. Ia dapat dikatakan sebagai tulang punggung atau bahkan jantung dari kehidupan suatu negara. Tanpa didukung oleh ekonomi yang kuat, mustahil suatu negara dapat melaksanakan pembangunanpembangunan di bidang yang lain secara baik dan sempurna. Perkembangan perekonomian pada masa pemerintahan Dinasti Umayyah secara umum sudah mulai meningkat dibanding dengan masa sebelumnya. Meningkatnya perekonomian yang membawa kepada kemakmuran rakyat pada dinasti ini, sebenarnya tidak terlepas dari kebijaksanaan-kebijaksanaan yang dilakukan khalifah, di samping dukungan masyarakat terhadap kebijaksanaan-kebijaksanaan tersebut. Dalam masa permulaan pemerintahan Bani Abbasiyyah, pertumbuhan ekonomi (economic growth) dikatakan cukup stabil dan menunjukkan angka vertikal. Devism negara berlimpah-limpah, uang masuk lebih banyak dari pada pengeluaran. Bila kita melakukan refleksi histories, masa keemasan Islam bertitik zenith pada periode Dinasti Umayyah dan Abbasiyah, setelah keruntuhan Baghdad pada tahun 1258 M. maka secara politis menandakan tenggelamnya masa kejayaan tersebut. Demikian hingga menjelang abad ke-16 M, yang merupakan masa yang teramat krusial bagi sejarah peradaban Islam. Dunia Islam mulai bangkit kembali dengan ditandai oleh munculnya 3 (tiga) kerajaan besar, yaitu Kerajaan Usmani di Turki.

\section{Masa Pemerintahan Bani Umayyah.}

Salah satu tokoh islam yang berhasil menjadi khalifah pada masa bani umayyah adalah umar bin abdul aziz. Khalifah Umar bin Abdul Aziz dalam masa kepemimpinannya mencapai masa yang gemilang dalam mensejahterakan masyarakat ketika itu. Tercatat hingga tahun 717 Masehi, kegemilangan Islam datang kembali dalam masa kepemimpinan Umar bin Abdul Aziz dari Bani Umayah. Semua itu adalah bukti bahwa Khalifah Umar merubah dan menerapkan beberapa kebijakan baru yang lebih produktif guna meningkatkan kesejahteraan masyarakat. ${ }^{1}$

A. Kondisi Sosial Masyarakat Dinasti Bani Umayyah,

a. Kondisi sosial sekalipun pro-arab-isme, namun tidak menjauhkan diri dari golongan non-muslim. Bahkan golongan nonislam memperoleh jabatan-jabatan dalam pemerintahan dan

\footnotetext{
${ }^{1}$ Silvi Kusumastuti Dan Mohammad Ghozali, Konsep Welfare State Pada Kebijakan Umar Bin Abdil Aziz Sebagai Khalifah Bani Umayyah, Jurnal Laa Maisyir,Volume 6, Nomor 2, Juli 2019:282-296, Diakses Pada Tanggal 31 Maret 2021.
} 
dipercaya oleh para raja

b. Kebijaksanaan Politik Dinasti Umayyah.

Ada beberapa kebijaksanaan politik yang dilaksanakan pada masa Dinassti Umayyah, yaitu : pemindahan dari Madinah ke Damaskus, Mua'awiyah memberi penghargaan kepada orang-orang yang berjasa dalam perjuangan mencapai puncak kekuasaan, Menumpas orang-orang yang beroposisi yang dianggap berbahaya, Membangun kekuatan militer yang terdiri dari tiga angkatan, darat, laut, dan kepolisian yang tangguh dan loyal, Meneruskan perluasan wilayah kekuasaan Islam baik ke timur maupun ke barat.

B. Perkembangan ekonomi dan administrasi pada dinasti baniumayyah

Cari Brockelmann menegaskan bahwa: Pada tahun 693 khalifah Abdul Malik secara bulat menetapkan untuk mencetak uang sendiri di damaskus. Sementara itu Hajjaj pada tahun berikutnya melakukan hal yang sama. Akibatnya masyarakat Arab sudah mulai mengenal sistem perhitungan. Kemudian Pengelolaan administrasi dalam struktur pemerintahan Dinasti Bani Umayyah merupakan penyempurnaan dari pemerintahan khulafaur rasyidin yang diciptakan oleh Khalifah Umar. menjadi wilayah provinsi

\section{Masa Pemerintahan Bani Abbasiyah}

Perkembangan politik : Daulah Abbasiyyah berkuasa kurang lebih selama lima abad, yaitu mulai tahun $132 \mathrm{H} / 750 \mathrm{M}-656 \mathrm{H} / 1258 \mathrm{M}$. Dalam masa permulaan pemerintahan Bani Abbasiyyah, pertumbuhan ekonomi (economic growth) dikatakan cukup stabil dan menunjukkan angka vertikal. Devis negara penuh berlimpah-limpah, uang masuk lebih banyak dari pada pengeluaran. Adapun Sektor-sektor perekonomian yang dikembangkan meliputi pertanian, perindustrian, dan perdagangan. Dalam bidang administrasi negara, masa Daulah Abbasiyyah tidak jauh berbeda dengan masa Umayyah. Hanya saja, pada masa ini telah mengalami kemajuan-kemajuan, perbaikan, dan penyempurnaan. ${ }^{2}$

\section{Masa Pemerintahan Turki Utsamani}

Dalam usaha memahami perkembangan lslam secara obyektif dan komprehensif memang sangat signifikan. Hal ini mengingat perkembangan sosial politik, sosio-keagamaan dan ekonomi bukanlah sesuatu yang bersifat konstan, melainkan dinamis Dengan pemahaman konteks tersebut, diharapkan akan diperoleh sebuah perspektif yang tidak bersifat simplifiet. Berkenaan dengan ini setidaknya ada beberapa hal yang bisa dijadikan pisau analisis, di antaranya kondisi sosial politik, sosio-keagamaan, sosio-pendidikan dan ekonomi. ${ }^{3}$

\footnotetext{
${ }^{2}$ Naila Farah, Perkembangan Ekonomi Dan Administrasi Pada Masa Bani Umayyah Dan Bani Abbasiyah, jurnal kajian ekonomi dan perbankan, no.2, vol.6, tahun 2014. Dikases pada tanggal 31 maret 2021.

${ }^{3}$ Rahmawati Dan Mohd. Azizuddin Mohd Sani, Perkembangan Peradaban Islam, Jurnal Rihlah Vol. 1,No.1, Tahun 2013, Diakses Pada Tanggal 31 Maret 2021.
} 